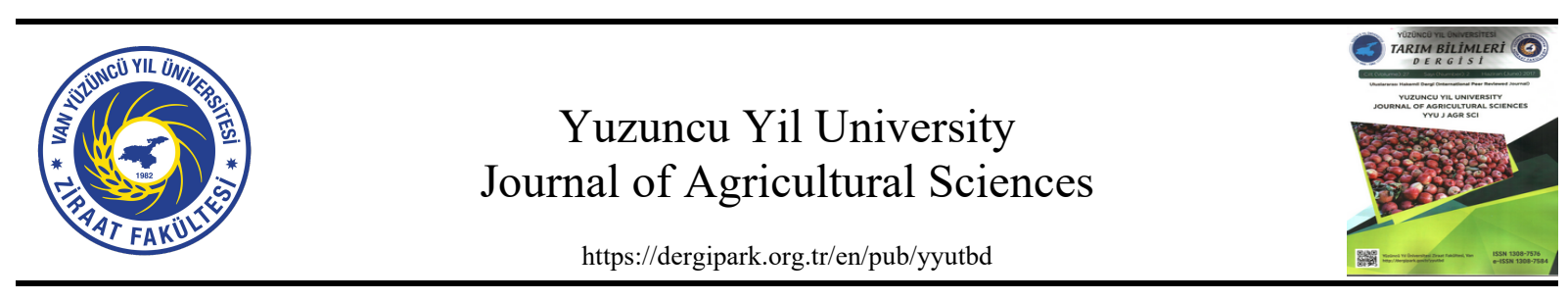

Research Article

\title{
Molecular identification of 'Candidatus Phytoplasma solani' using SecY and Vmp1 Genes in Tomato Plants from Van province
}

\author{
Mustafa USTA ${ }^{1}$, Abdullah GÜLLER ${ }^{2}$, Serap DEMİREL ${ }^{* 3}$ \\ ${ }^{1}$ Van Yüzüncü Yıl University, Faculty of Agriculture, Department of Plant Protection, 65000, Van, Turkey \\ ${ }^{2}$ Bingöl University, Faculty of Agriculture, Department of Plant Protection, 12000 Bingöl, Turkey \\ ${ }^{3}$ Van Yüzüncü Yıl University, Faculty of Science, Department of Molecular Biology and Genetic, 65000, Van, \\ Turkey
}

${ }^{1}$ https://orcid.org/0000-0002-3940-2774 ${ }^{2}$ https://orcid.org/0000-0003-3887-4208 ${ }^{3}$ https://orcid.org/0000-0002-3102-4924

*Corresponding author e-mail: serap_comart@hotmail.com

\section{ArticleInfo}

Received: 09.06.2021

Accepted: 15.11.2021

Online Published: 15.12.2021

DOI: 10.29133/yyutbd.950047

Keywords

'Ca. P. solani',

Phylogeny,

$\operatorname{SecY}$,

Tomato,

Turkey,

Vmpl.
Abstract: Tomato (Solanum lycopersicum) is one of the most financially important vegetable crops. It is a species belonging to the Solanaceae family and is cultivated in many countries, including Turkey. The natural presence of 'Candidatus Phytoplasma solani' ('Ca. P. solani') from the Stolbur group (16SrXII) in tomato plants is extensively characterized based on the 16S rRNA gene worldwide. Tomato plants displaying abnormality and sterility of flower, purpling, and bushy appearance were observed in the Van province, Turkey. DNA extraction from tomato leaves was performed, and the extracted DNA was used to amplify $16 \mathrm{~S}$ rRNA sequences using universal primer pairs by double PCR assays. After confirming the presence of the probable agent (' $\mathrm{Ca}$. P. solani'), nested PCR testing was performed using an appropriate primer set amplifying the $\mathrm{Sec} Y$ and $\mathrm{Vmpl}$ genes of the same DNAs. Amplified PCR yields were then cloned into a pGEM T-Easy vector and sequenced by New Generation System (NGS). Sequenced 1438 bp nucleotides for Vmpl gene (MN104838) and 905 bp nucleotides for $\operatorname{Sec} Y$ gene (MN125054) revealed $97.38 \%$ and $100 \%$ maximum nucleotide similarity with formerly published $\mathrm{Vmpl}$ and $\mathrm{Sec} Y$ gene sequences of 'Ca. P. solani' species belonged to the Stolbur group (16Sr-XII), respectively. According to the phylogenetic tree created using our gene sequences from ' $\mathrm{Ca}$. P. solani', Vmpl, and $\operatorname{Sec} Y$ gene sequences showed a highly phylogenetic affinity with the same sequences of the same agent from Serbia and France, respectively. To the best of our knowledge, this study is the first report to reveal the phylogenetic relationships of ' $\mathrm{Ca}$. P. solani' in stolbur group (16Sr XII-A) using $\mathrm{Sec} Y$ and $\mathrm{Vmpl}$ genes in the tomato plant in Turkey based on the non-ribosomal genes.

\section{Van'dan Domates Bitkilerinde SecY ve Vmpl Genlerini Kullanarak 'Candidatus Phytoplasma solani'nin Moleküler Tanımlanması}

\section{Makale Bilgileri}

Geliș: 09.06.2021

Kabul: 15.11 .2021

Online Yayınlanma: 15.12.202

DOI: $10.29133 /$ yyutbd.950047
Öz: Domates (Solanum lycopersicum) finansal olarak en öemli sebze bitkilerinden biridir. Solanaceae familyasına ait olan domates Türkiye'nin de içerisinde bulunduğu bir çok ülkede kültürü yapılmaktadır. Domates bitkilerinde Stolbur gruptan 'Candidatus Phytoplasma solani'nin doğal varlığ̀ dünya genelinde geniş ölçüde 16S rRNA geni üzerine dayalı olarak gerçekleştirilmiştir. Çiçekte anormallik ve kırıslık, morluk ve gür görünüm sergileyen domates bitkileri Türkiye'nin Van ilçesinde gözlendi. Domates yapraklarından DNA izolasyonu gerçekleştirildi. İzole edilen DNA'lar evrensel primer çiftleri çift PCR 
Anahtar Kelimeler

'Ca. P. solani',

Filogeni,

$\operatorname{SecY}$,

Domates,

Türkiye,

Vmpl. tekniğiyle 16S rRNA sekansını çoğaltmak için kalıp olarak kullanıldı. Muhtemel ajanın varlığının doğrulanmasının ardından, Nested PCR tekniği aynı DNA'ların $S e c Y$ ve $V m p l$ genlerini amplifiye eden uygun primer çiftleri kullanılarak gerçekleştirildi. Çoğaltılan PCR ürünleri daha sonra pGEM T-Easy vektöre klonlandı ve yeni nesil sekanlama teknolojisi ile sekanslandı. 1438 bp'lik Vmp1 geni ve 905 bp'lik $\operatorname{Sec} Y$ genine ait nükleotid dizileri Stolbur grupa ait ' $C a$. $\mathrm{P}$ solani'nin daha önceleri yayınlanan Vmpl ve SecY geni ile sırası ile 97.38\% and $100 \%$ maximum nükleotid benzerliği göstermiştir. ' $\mathrm{Ca}$. P solani'ye ait bizim gen sekanslarımız ile oluşturulan filogenetik ağaca göre $V m p l$ ve $S e c Y$ geni sekansları sırasıyla Sırbistan ve Fransa'dan aynı ajanın aynı genleri ile yüksek filogenetik ilişki göstermiştir. Bizim bilgimize göre bu çalışma ribosomal olmayan genlere dayalı Türkiye'de domates bitkilerinde $\operatorname{SecY}$ and $V m p l$ genlerini kullanarak stolbur grupda (16Sr XII-A) 'Ca. P. solani'nin filogenetik ilişkisini ortaya koyan ilk rapordur.

\section{Introduction}

Tomato (Solanum lycopersicum), which is of South American origin in the Solanaceae family, and cultivated in 175 countries, is a commercial vegetable crop grown in almost every part of the world due to its wide range of uses. China is the leading country in the production of tomatoes; thereafter comes India and the USA. According to FAO data, Turkey ranks third among the world countries with a tomato production of approximately 13 million tons (Faostat, 2019). Tomato is one of the main vegetables in Van province, with a yield of 15017 tons in 566.3 hectares (Anonymous, 2016).

Phytoplasmas are one of the major plant parasites that limit solanaceous crops, including tomatoes. Phytoplasmas were firstly discovered in 1960 (Bai et al. 2006). Phytoplasmas, formerly known as mycoplasma-like organisms (MLO), have a wide-host range, $\mathrm{Gram}^{+}$, without cell walls, hardly cultured, pleomorphic prokaryotes 8-10 nm in size, with minimal size DNA genome (Sugio et al., 2011; Contaldo et al., 2012). In extensive evolutionary research, phytoplasmas are included in the Mollicutes class. It is difficult to classify phytoplasmas according to the criteria applied to Mollicutes taxonomy since it is proved impossible to obtain pure cultures of any phytoplasma and the lack of accessible phenotypic principle (Vandamme et al., 1996; Razin et al., 1998). The 16S rRNA gene has fairly conserved sequences and is mostly used for phylogenetic research of prokaryotes. The sequence of this gene has been used in the recent phytoplasma taxonomy as the primary phylogenetic parameter (Lee et al., 1993: Seemüller et al., 1998). Therefore, a 2.5\% uniqueness threshold in the 16s rRNA gene is still applied as a guideline for accepting a new species (IRPCM, 2004). Different phytoplasma strains biologically and ecologically fail to meet the requirement of sharing $<97.5 \%$ sequence similarity with current 'Candidatus Phytoplasma' but warrant designation of a new taxon can't be easily classified. In this case, extra unique properties like host types and insect vectors or additional molecular markers need to be included for finer speciation and differentiation of phytoplasmas (Martini et al., 2007).

Recently, more than 100 phytoplasma species have been defined from edible crops, weeds, ornamental plants, woody and fruit trees, parasite plants, and insects (Bertaccini and Duduk, 2009). Phytoplasmas are biotrophic microorganisms that spread with aphids sucking phloem sap in a persistent manner and parasitic plants (Suzuki et al., 2006; Shimizu and Aoki, 2019). 'Ca. P. solani' belonging to 16SrXII-A subgroup (Stolbur group) infect the crops with economic significance from the family of both Solanaceae and Apiaceae, causing severe crop loss (Carraro et al., 2008; Navrátil et al., 2009).

The $\mathrm{Sec} Y$ gene is a promising marker gene for finer separation in the successful differentiation of biologically and ecologically close phytoplasma strains. The $\operatorname{Sec} Y$ ( $\operatorname{prIA})$ gene, which codes for the protein translocase subunit, is one of the main subunits of the cytoplasmic membrane, which is necessary for translocation of the exo-cytoplasmic proteins through the cell membrane (Akiyama and Ito, 1987; Lee et al., 2010). The $\operatorname{Sec} Y$ gene located in the operator-distal part of the SPC ribosomal protein operon is most likely composed of six cytoplasmic and five periplasmic parts and ten transmembrane segments (Ito, 1990). The PCR-RFLP assays of variable membrane protein-1 amplicons (formerly termed as stoll $\mathrm{H} 10$ and now named $\mathrm{vmpl}$ ) were also studied to elucidate the epidemiology and fine differentiation of the phytoplasma disease (Murolo and Romanazzi, 2015). The vmp1 gene possesses a high degree of genetic variability and is in direct contact with the host cells. Because of this feature, Vmpl is used as a notable marker gene for molecular detection and epidemiological research of bacteria. It also provides 
a broad perspective on the monitoring of pathogen movements, revealing the history of the disease and understanding their spreading routes in uncultivable organisms (Kakizawa et al., 2006; Li et al., 2009; Cimerman et al., 2009; Baric et al., 2011).

Stolbur phytoplasma is an infectious agent in edible plants such as solanaceous vegetables (pepper, eggplant, and tomato), vine, sugar beet, strawberry, and celery in Europe, Asia, America, Africa, and Australia (Garnier, 2000). It also affects economically important different fruit crops, including peach (Allahverdi et al., 2018), blackberry (Kuzmanović et al., 2011), and avocado (Laviña et al., 2002), and causes their product loss or even death. In addition to being extensively seen in solanaceous vegetables, its presence has also been reported in different ornamental and wild plants such as marigold (Alp et al., 2016), petunia (Chung et al., 2013), evening primrose (Adamovic et al., 2014) and chicory (Pavlovic et al., 2014). Symptoms of stolbur infection observed in tomatoes are leaf rolling, leaf discoloration, floral distortion, sepal hypertrophy, angular fruit, big bud, and stunting (Çağlar et al., 2010).

The aim of this study is to detect the phytoplasmic agent restricting tomato production by PCR assays using $\mathrm{SecY}$ and $\mathrm{Vmpl}$ genes in phytoplasma-suspected tomato plants and assess the molecular and phylogenetic analysis of both genes.

\section{Material and Methods}

\subsection{Plant samples}

Leaf samples from 13 tomato plants displaying phytoplasma-specific symptoms were collected from Van province (Turkey) in the autumn season of 2020. The leaves were quickly brought to the laboratory and stored at -20 until used. For molecular analysis, $0.1 \mathrm{~g}$ of frozen sample was subjected to DNA extraction using GeneJET Genomic DNA Purification Kit (Thermo Scientific). Eluted DNA of $35 \mu l$ was preserved at $-80^{\circ} \mathrm{C}$ until processed.

\subsection{Amplification of $\operatorname{Sec} Y$ and $V m p 1$ genes from ' $C a$. P. solani'}

Firstly, phytoplasmic agent, ' $C a$. P. solani', was identified by PCR-RFLP analysis performed using R16mF2/R16mR1 and R16F2n/R16R2 primer pairs. Later, primer sets designed by Fialová et al. (2009) based on $\mathrm{SecY}$ and $\mathrm{Vmpl}$ gene sequences were utilized in two step PCR amplification, direct PCR, and nested PCR (Table 1). The $50 \mu$ volume PCR-mix containing $5 \mu 1$ extracted DNA (25ng) consisted of $5 \mu 1$ 10X PCR Buffer, $1 \mu 1$ 10mM dNTP mix, $36.6 \mu 1$ RNase free water, $3 \mu 1 \mathrm{MgCl}_{2}(25 \mathrm{mM})$, $1 \mu 1(20 \mathrm{pmol})$ forward and reverse primer pairs, with the addition of $0.4 \mu 1$ Taq DNA polymerase enzyme $\left(5 \mathrm{U} \mathrm{l}^{-1}\right)$ (Thermo Scientific, USA). PosecF1/PosecR1 (direct PCR) and then PosecF3/PosecR3 primers (nested PCR) was used for $\operatorname{Sec} Y$ amplification, StolH10F1/StolH10R1 (direct PCR) followed by TYPH10F/TYPH10R primer sets (nested PCR) was used for Vmpl gene amplification (Table 1). Direct PCR products diluted 30-fold by distilled water were used as a template for nested PCR. Mix without DNA template was used as a negative control. Amplified yields were assessed on agarose gel (1\%) using a $10 \mathrm{~kb}$ DNA ladder under a UV trans-illuminator device.

Table 1. The primer sets and temperature cycles utilized in the PCR tests. PD: pre-denaturation, D: denaturation, A: annealing, E: extension

\begin{tabular}{|c|c|c|c|c|}
\hline Gene & $\begin{array}{l}\text { Primer } \\
\text { name }\end{array}$ & Primer sequence & PCR type & $\begin{array}{c}\text { PCR cycle conditions and } \\
\text { durations }\end{array}$ \\
\hline \multirow{4}{*}{$\operatorname{Sec} Y$} & PosecF1 & TCTGCTTTGCCTTTGCCTTT & \multirow{2}{*}{ Direct } & PD: $94^{\circ} \mathrm{C}-4 \mathrm{~m}$ (1 cycle $)$ \\
\hline & PosecR1 & ATTAGTAAACTAGTTCCTCC & & D: $94^{\circ} \mathrm{C}-30 \mathrm{~s}$ \\
\hline & PosecF3 & GGATTGATAGATGCTGCCCC & & A: $52^{\circ} \mathrm{C}-30 \mathrm{~s}\left(55^{\circ} \mathrm{C}\right.$ for nested $)$ \\
\hline & PosecR3 & GCCCCTATAACGGTGATTTTGA & Nested & $\begin{array}{c}\mathbf{E}: 72^{\circ} \mathrm{C}-2 \mathrm{~m}(1.5 \mathrm{~m} \text { for nested }) \\
(35 \text { cycles })\end{array}$ \\
\hline \multirow{4}{*}{ Vmp1 } & StolH10F1 & AGGTTGTAAAATCTTTTATGT & \multirow{2}{*}{ Direct } & PD: $95^{\circ} \mathrm{C}-3 \mathrm{~m}$ (1 cycle $)$ \\
\hline & StolH10R1 & GCGGATGGCTTTTCATTATTTGAC & & D: $95^{\circ} \mathrm{C}-30 \mathrm{~s}$ \\
\hline & TYPH10F & AACGTTCATCAACAATCAGTC & & A: $54^{\circ} \mathrm{C}-30 \mathrm{~s}\left(62^{\circ} \mathrm{C}\right.$ for nested $)$ \\
\hline & TYPH10R & CACTTCTTTCAGGCAACTTC & Nested & E: $72^{\circ} \mathrm{C}-1 \mathrm{~m}$ \\
\hline
\end{tabular}




\subsection{Cloning of PCR amplicons and nucleotide sequencing of SecY and $\mathrm{Vmpl}$ genes}

In order to reveal the nucleotide sequences, the $100 \mu 1$ of nested PCR-amplified products were loaded into 1\% agarose gel, cut DNA fragments purified with GeneJet agarose gel extraction kit (Cat. No. K0691, Thermo). ). The purified DNA fragments were cloned directly into the proper prokaryotic cloning vector (pGEM T-Easy) using a competent cell (E. coli JM 109 strain). Recombinant plasmids containing the inserted gene were determined by blue-white selection and propagated in a liquid LB medium. And then, six plasmid purification was performed with GeneJet Plasmid Miniprep Kit (Cat. No. K0503, Thermo). After recombinant plasmid containing the gene of interest verified by PCR using gene-specific primers, one plasmid, including each gene, sent for nucleotide sequencing (Sentebiolab/ANKARA). All kits were used according to the manufacturer's instructions. The nucleotide sequences of the $\operatorname{Sec} Y$ and $V m p l$ genes were stored with accession numbers (MN125054 and MN104838) in the GenBank (NCBI

\subsection{Phylogenetic analysis of $\operatorname{Sec} Y$ and $V m p 1$ Sequences}

Based on $\mathrm{SecY}$ and $\mathrm{Vmpl}$ sequences, the phylogenetic inter-relationships among strains of the stolbur group and other phytoplasma groups were evaluated. Partial sequences of members of the 16SrXII group and other phytoplasma strains deposited in GenBank were aligned by using CLC Main Workbench Software version 6.2.2. A phylogenetic tree was created using Mega 7 software, with 1000 bootstrap values based on the neighbor-joining method. For the phylogenetic tree generated for $\operatorname{Sec} Y$ genes, $\operatorname{Sec} Y$ sequences from different phytoplasmic groups were included as well as the STOL group, but not included for $V m p l$ gene duo to lack the other Vmpl gene sequences from the STOL group in GenBank.

\section{Results and Discussion}

Phytoplasmas interfere with the host's hormone regulation, resulting in remarkable symptoms such as witches' broom, yellowing, reddening and purpling, phyllody, dieback, upward rolling, infertility, woody, and tasteless fruit formation, and stunting (Duduk and Bertaccini, 2011). In our study, Stolbur-diseased tomato plants exhibited striking symptom development such as elongated calyx, infertility and flower deformities, and scrub (Fig 1), which are consistent with those previously reported by many researchers (Pracros et al., 2006; Azza and Eman, 2016; Sakalieva, 2020). The occurrence of stolbur phytoplasma of tomato in Turkey was first known in 1953 and subsequently from potatoes in 1965 (Tanrikut, 1953, Sahtiyanc1, 1966). Moreover, the current study revealed the presence of ' $\mathrm{Ca}$. P. solani' in tomato plants in Van province of Turkey by molecular analysis.

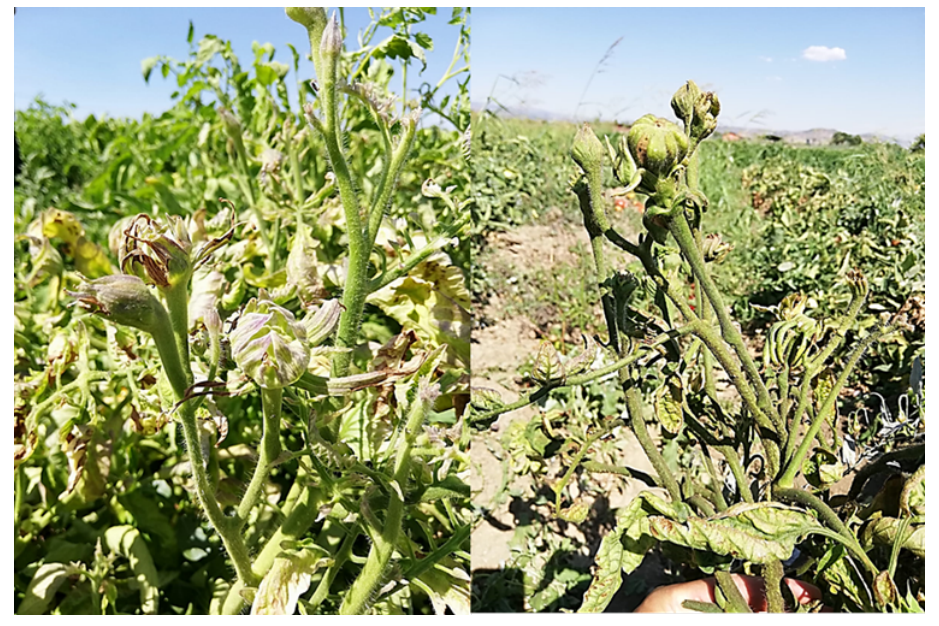

Figure 1. Various types of symptoms triggered by stolbur infection on tomato plants.

Phytoplasmas are basically divided into 33 groups according to the RFLP-based grouping of the largely evolutionarily conserved ribosomal 16S rRNA gene (Dickinson and Hodgetts, 2013; Bertaccini 
et al., 2014). However, epidemiological studies have shown that different phytoplasma strains which have very close genetic affinity are not easily discriminated by analysis of the 16S rRNA gene sequence only (Martini et al., 2007). In the classification of phytoplasmas, several bacterial genetic markers are also used as supporting tools for more detailed differentiation. Lee et al. (2010) showed that finer differentiation of strains into subgroups of 'Candidatus Phytoplasma' was provided by the sec Y gene rather than the 16S rRNA gene. Davis et al. (2013) also signified SecY gene could be used in the taxonomy of phytoplasma. Markers based on 23S rRNA and SecA gene successfully discriminated candidate species of 'Candidatus Pyhtoplasma' (Hodgetts et al. 2008). Several genetic markers such as imp, tuf, Vmp1, rp, cpn60UT, rpoB, AY-WB, and SAP11 has been used in phylogenetic analyses for detailed separation of phytoplasma strains (Martini et al., 2007; Kakizawa et al., 2009; Sugio et al., 2010; Wu and Baldwin, 2010; Sugawara et al., 2012; Alvarez et al., 2014; Pérez-López et al., 2014; 2018; Rashid et al., 2018).

In our study, two tomato plants showing phytoplasma-like symptoms were PCR-positive. Based on PCR-RFLP analysis of 16S rRNA gene using universal primer sets, we confirmed the presence of ' $\mathrm{Ca}$. P. solani' from the stolbur group in diseased tomato plants. One of the stol-infected DNAs was randomly selected, and their $\operatorname{Sec} Y$ and $V m p l$ genes were successfully amplified using related primer sets (Table 1). Nested PCR amplification resulted in $1438 \mathrm{bp}$ for the Vmpl gene and a $905 \mathrm{bp}$ DNA fragment for the $\mathrm{Sec} Y$ gene (Fig 2). Related sequences of ' $\mathrm{Ca}$. P. solani' were recorded in the GenBank with Acc. No. MN104838 and MN125054, respectively. Interestingly, although the same primer sets were used, DNA fragments of distinct length were obtained in PCR amplification studies performed by various researchers separately, indicating that the $S e c Y$ and $V m p l$ genes have a high degree of variability in terms of DNA fragments with different lengths (Fialová et al., 2009; Lee et al., 2010).

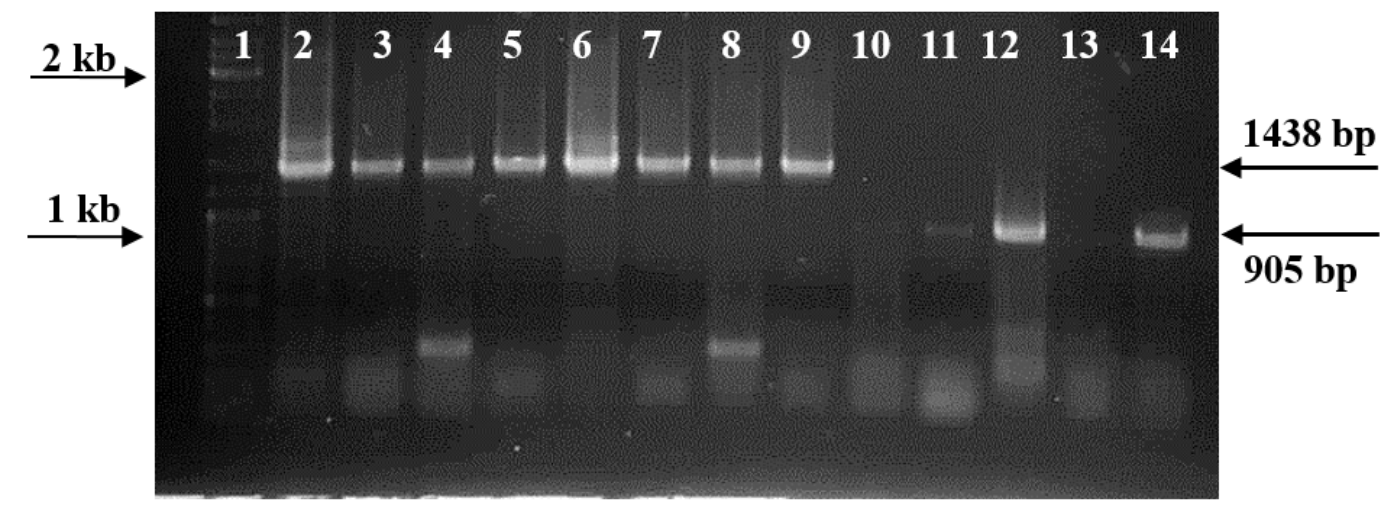

Figure 2. Agarose gel profile of $\mathrm{Vmpl}$ and $\mathrm{Sec} Y$ genes obtained from ' $\mathrm{Ca}$. P. solani' by Nested-PCR assay from suspected tomato plants, 1: Marker $(10 \mathrm{~kb})$; 2-9: DNA fragments of $V m p 1$ gene of infected tomato; 12 and 13: DNA fragments of $\operatorname{Sec} Y$ gene of infected tomato.

According to BLAST analysis, the sequence identity obtained from TYPH10F/TYPH10R primers for $V m p l$ amplicons ranged from $97.38 \%$ to $91.80 \%$. The $S e c Y$ gene sequence amplified by PosecF3/PosecR3 primers showed sequence identity in the range of $99.01 \%-100 \%$. These data indicate that the $\sec Y$ gene is more stable than the $V m p l$ gene of ' $\mathrm{Ca}$. P. solani'. PosecF3/PosecR3 primed SecY sequences, and TYPH10F/TYPH10R primed Vmp1 sequences were aligned with the same sequences from ' $\mathrm{Ca}$. P. solani' from different origins and their phylogenetic relationships were revealed. As shown in Fig 3, we determined that the 905 base $\mathrm{Sec} Y$ sequence obtained from ' $\mathrm{Ca}$. P. solani' from tomato plants in Van province (Turkey) showed a phylogenetic affinity with the 841 base French isolates (AM992083) from the tomato plant. In the phylogenetic tree, our $\operatorname{Sec} Y$ sequence (MN125054) is clustered with ' $\mathrm{Ca}$. P. solani' isolates from the STOL group, although there are $\operatorname{Sec} Y$ gene sequences from different $16 \mathrm{Sr}$ groups/subgroups (16SrI, II, III, IV, V, VI, VII, VIII, X, XIII), which indicate that $\mathrm{Sec} Y$ gene sequences from the same 16Sr group are more compatible with each other. Unlike the $\operatorname{Sec} Y$ gene, the Vmpl gene exhibited greater host-independent gene similarity based on the phylogenetic tree generated using ' $\mathrm{Ca}$. P. solani' isolates isolated from different hosts. As seen in Fig. 3, our Vmpl sequence (1438 bp, MN104838) showed a phylogenetic affinity with Serbia isolate (1053 bp, KC703030) from the insect Reptalus quinquecostatus. 


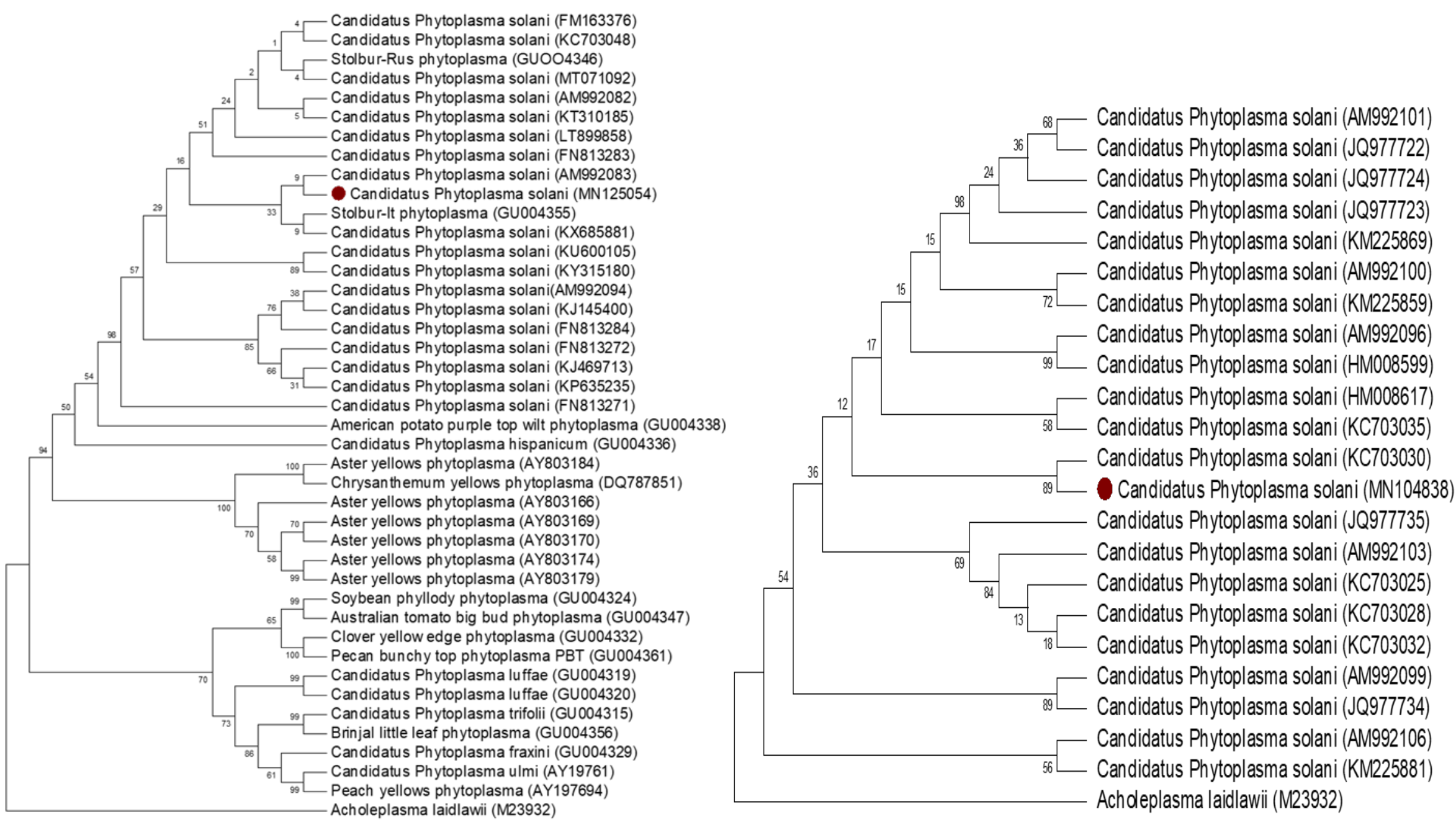

Figure 3. Phylogenetic trees created by using Neighbor-Joining method based on the $\operatorname{Sec} Y$ gene sequences consisting of $1016 \mathrm{Sr}$ subgroups and numerous subgroups (left) and Vmpl gene sequences (right). Bootstrap scores are displayed on the main branches. A. laidlawii was assigned as outgroup. 
In the world, ' $\mathrm{Ca}$. P. solani' in the 16 SrXII-A group commonly affects solanaceous crops worldwide, as well as in Turkey (Mitrovic et al., 2016; Ember et al., 2011). In addition to the 16Sr ribosomal genes, other non-ribosomal genes have begun to be widely used in phytoplasma taxonomy. In Turkey, there are many studies reporting the presence of ' $\mathrm{Ca}$. P. solani' agent based on 16SrRNA gene using universal primer sets related to phytoplasma epidemics in many agro-economic products (Oksal et al., 2017; Usta et al., 2017; Usta et al., 2018; Oksal, 2020). Güller and Usta (2020) detected both $C a$. P solani (16SrXII) and $C a$. P. trifolii (16SrVI-A) in tomato plants from Turkey. However, there are no records revealing the phylogenetic relationship of the related agent using different marker genes such as $\operatorname{Sec} Y$ and $V m p l$. To our knowledge, this research is the first phylogenetic investigation of ' $\mathrm{Ca}$. P. solani' belonging to 16SrXII-A group infecting tomatoes in Turkey based on these genes. Phylogenetic information of any organism provides insight into our understanding of its biodiversity, distribution, origin, evolutionary history, and relationship with others. Therefore, this study is significant in terms of the first phylogenetic report using $S e c Y$ and $V m p l$ genes in tomatoes and providing a source for other studies to be carried out in the future.

\section{References}

Adamovic, D., Djalovic, I., Mitrovic, P., Kojic, S., Starovic, M., Purar, B., \& Josic, D. (2014). First report of 16SrXII-A subgroup Phytoplasma (Stolbur) associated with reddening of Oenothera biennis in Serbia. Plant disease, 98(6), 841-841.

Ahrens, U., \& Seemüller, E. (1992). Detection of DNA of plant pathogenic mycoplasmalike organisms by a polymerase chain reaction that amplifies a sequence of the $16 \mathrm{~S}$ rRNA gene. Phytopathology, 82(8), 828-832.

Akiyama, Y., \& Ito, K. (1987). Topology analysis of the SecY protein, an integral membrane protein involved in protein export in Escherichia coli. The EMBO Journal, 6(11), 3465-3470.

Aksoy, A., \& Kaymak, H. Ç. (2016). Türkiye Domates Sektörüne Genel Bakış. Ĭğdır Üniversitesi Fen Bilimleri Enstitü Dergisi, 6(2), 121-129.

Allahverdi, T., Rahimian, H., \& Rastgou, M. (2018). Peach and nectarine affected with 16SrXII and 16SrIX phytoplasma groups in Northern provinces of Iran. Yüzüncü Yil Üniversitesi Journal of Agricultural Sciences, 28 (Special Issue), 150-158.

Alp, Ş., Usta, M., Sipahioğlu, H. M., \& Güller A. (2016). "First report of "Candidatus Phytoplasma solani" on a new host marigold (Tagetes erecta L.)". Turkish Journal of Agriculture and Forestry, 40, 311-318.

Al-Subhi, A. M., Hogenhout, S. A., Al-Yahyai, R. A., Al-Sadi, \& A. M. (2017). Classification of a new phytoplasma subgroup 16SrII-W associated with Crotalaria witches' broom diseases in Oman based on multigene sequence analysis. BMC Microbiology, 17(1), 221.

Alvarez, E., Mejía, J. F., Contaldo, N., Paltrinieri, S., Duduk, B., \& Bertaccini, A. (2014). 'Candidatus Phytoplasma asteris' strains associated with oil palm lethal wilt in Colombia. Plant Disease, 98 , 311-318.

Anonymous (2016). Van with selected indicators. www.tuik.gov.tr/ province Indicators / provinces / VAN.pdf. Access date: 15.03.2017.

Azza, G. F., \& Eman, A. H. M. (2016). Detection of stolbur phytoplasma in tomato by a specific DNA hybridization. Research Journal Biotechnology, 11(6), 30-34.

Bai, X., Zhang, J., Ewing, A., Miller, S.A., Radek, A.J., Shevchenko, D.V., Tsukerman, K., Walunas, T., Lapidus, A., Campbell, J.W., \& Hogenhout, S. A. (2006). Living with genome instability: the adaptation of phytoplasmas to diverse environments of their insect and plant hosts. Journal of Bacteriology, 188, 3682-3696.

Baric, S., Berger, J., Cainelli, C., Kerschbamer, C., \& Dalla Via, J. (2011). Molecular typing of 'Candidatus Phytoplasma mali' and epidemic history tracing by a combined T-RFLP/VNTR analysis approach. European Journal of Plant Pathology, 131, 573-84.

Bertaccini, A., \& Duduk, B. (2009). Phytoplasma and phytoplasma diseases: a review of recent research. Phytopathologia mediterranea, 48, 355-378.

Bertaccini, A., Duduk, B., Paltrinieri, S., \& Contaldo, N. (2014). "Phytoplasmas and Phytoplasma Diseases: A Severe Treat to Agriculture". American Journal of Plant Sciences, 5(12), 17631788. 
Carraro, L., Ferrini, F., Martini, M., Ermacora, P., \& Loi, N. (2008) A serious epidemic of Stolbur on celery. Journal Plant Pathology, 90, 131-135.

Chung, B. N., Jeong, M. I., Choi, S. K., Joa, J. H., San Choi, K., \& Choi, I. M. (2013). Occurrence of stolbur phytoplasma disease in spreading type Petunia hybrida cultivars in Korea. The plant pathology journal, 29(4), 465.

Cimerman, A., Pacifico, D., Salar, P., Marzachi, C., \& Foissac, X. (2009). Striking diversity of vmp1, a variable gene encoding a putative membrane protein of the stolbur phytoplasma. Applied and Environmental Microbiology, 75, 2951-7.

Contaldo, N., Bertaccini, A., Paltrinieri, S., Windsor, H. M., \& Windsor G. D. (2012). “Axenic culture of plant pathogenic phytoplasmas". Phytopathologia Mediterranea, 51, 607-617.

Çağlar, B.K., Elbeaino, T., Küsek, M., Pehlivan, D., Fidan, H., \& Portakaldalı, M. (2010). Stolbur Phytoplasma Infections in Potato and Tomato Plants from Different Locations in Turkey. The Journal of Plant Pathology, 39, 1-3.

Davis, R., Zhao, Y., Dally, E.L., Lee I.-M., Jomantiene, R., \& Douglas, S. M. (2013). 'Candidatus Phytoplasma pruni', a novel taxon associated with X-disease of stone fruits, Prunus spp.: multilocus characterization based on $16 \mathrm{~S}$ rRNA, secY, and ribosomal protein genes. International Journal of Systematic and Evolutionary Microbiology, 63, 766-776.

Deng, S.J., \& Hiruki, C. (1991). Genetic relatedness between two non-culturable mycoplasmalike organisms revealed by nucleic acid hybridization and polymerase chain reaction. Phytopathology, 81, 1475-1479.

Dickinson, M., \& Hodgetts, J. (2013). Phytoplasma methods and protocols, New York: Humana Press, The University of Nottingham, Nottingham, United Kingdom of Great Britain and Northern Ireland.

Doi Y., Teranaka, M., Yora, K., \& Asuyama, H. (1967). Mycoplasma or PLT grouplike microrganisms found in the phloem elements of plants infected with mulberry dwarf, potato witches' broom, aster yellows or pawlonia witches' broom. Annals of Phytopathological Society Japan, 33, 259 266.

Duduk, B., \& Bertaccini, A. (2011). Phytoplasma Classification: Taxonomy Based on 16S Ribosomal Gene, Is It Enough? Phytopathogenic Mollicutes, 1, 1-13.

Ember, I., Acs, Z., Munyaneza, J. E., Crosslin, J. M., \& Kolber, M. (2011). Survey and molecular detection of phytoplasmas associated with potato in Romania and southern Russia. European Journal of Plant Pathology, 130(3), 367-377.

Fao, (2019). https://www.fao.org/faostat/en/\#data/QCL/visualize. Accesion date: 01.11.2021

Fialová, R., Válová, P., Balakishiyeva, G., Danet, J. L., Šafárová, D., Foissac, X., \& Navrátil, M. (2009). Genetic variability of stolbur phytoplasma in annual crop and wild plant species in south Moravia. Journal of Plant Pathology, 411-416.

Ganaie, M.M., Raja, V., Reshi, Z.A., \& Verma, V. (2018). Family Solanaceae: Taxonomy and modern trends. Annals of plant science, 7(9), 2403-2414.

Garnier, M. (2000). The stolbur phytoplasma: an ubiquitous agent. C. R. Acad. Agric. France, 86, $27-$ 33.

Güller, A., \& Usta, M. (2020). Stolbur and Clover Proliferation Phytoplasma Infections in Tomato from Bingöl province, Turkey. Türk Tarım ve Doğa Bilimleri Dergisi, 7(4), 855-866.

Hodgetts, J., Boonham, N., Mumford, R., Harrison, N., \& Dickinson, M. (2008). Phytoplasma phylogenetics based on analysis of secA and 23S rRNA gene sequences for improved resolution of candidate species of 'Candidatus Phytoplasma'. International Journal of Systematic and Evolutionary Microbiology, 58(8), 1826-1837.

IRPCM, (2004). 'Candidatus Phytoplasma', a taxon for the wall-less, non-helical prokaryotes that colonize plant phloem and insects. Int J Syst Evol Microbiol, 54, 1243-1255.

Ito, K. (1990). Structure, Function, and Biogenesis of SecY, an Integral Membrane Protein Involved in Protein Export. Journal of Bioenergetics and Biomembranes, 22(3), 353-367.

Kakizawa, S., Oshima, K., Ishii, Y., Hoshi, A., Maejima, K., Jung, H-Y., Yamaji, Y., \& Namba, S. (2009). Cloning of immunodominantmembrane protein genes of phytoplasmas and their in planta expression. FEMS Microbiol Letter, 293, 92-101.

Kakizawa, S., Oshima, K., \& Namba, S. (2006). Diversity and functional importance of phytoplasma membrane proteins. Trends in Microbiology, 14, 254-256. 
Kuzmanović, S., Starović, M., Pavlović, S., Gavrilović, V., Aleksić, G., Stojanović, S., \& Jošić, D. (2011). Detection of Stolbur phytoplasma on blackberry: A new natural host in Serbia. Genetika, 43(3), 559-568.

Laviña, A., Batlle, A., Faraco, J.G., \& Herrera, C.L. (2002). First report of stolbur phytoplasma in avocado in Spain. Plant disease, 86(6), 692-692.

Lee, I. M., Bottner-Parker, K. D., Zhao, Y., Davis, R. E., \& Harrison, N. A. (2010). Phylogenetic analysis and delineation of phytoplasmas based on secY gene sequences. International Journal of Systematic and Evolutionary Microbiology, 60(12), 2887-2897.

Lee, I. M., Hammond, R. W., Davis, R. E., \& Gundersen, D. E. (1993). Universal amplification and analysis of pathogen 16S rDNA for classification and identification of mycoplasmalike organisms. Phytopathology, 83(8), 834-842.

Li, W., Raoult, D., \& Fournier, P. E. (2009). Bacterial strain typing in the genomic era. FEMS microbiology reviews, 33(5), 892-916.

Martini, M., Lee, I. M., Bottner, K. D., Zhao, Y., Botti, S., Bertaccini, A., Harrison, N.A., Carraro, L., Marcone, C., Khan, A.J., \& Osler, R. (2007). Ribosomal protein gene-based phylogeny for finer differentiation and classification of phytoplasmas. International Journal of Systematic and Evolutionary Microbiology, 57(9), 2037-2051.

Mitrovic, M., Jakovljevic, M., Jovic, J., Krstic, O., Kosovac, A., Trivellone, V., Jermini, M., Toševski, I., \& Cvrkovic, T. (2016). 'Candidatus Phytoplasma solani' genotypes associated with potato stolbur in Serbia and the role of Hyalesthes obsoletus and Reptalus panzeri (Hemiptera, Cixiidae) as natural vectors. European Journal of Plant Pathology, 144(3), 619-630.

Murolo S., \& Romanazzi G. (2015). Molecular epidemiology of 'Candidatus Phytoplasma solani' by multilocus sequence analsis. Proceedings of the 18th Congress of ICVG, Ankara, TURKEY 711 September 2015.

Musetti, R., \& Favali, M. A. (2004). Microscopy techniques applied to the study of phytoplasma diseases: traditional and innovative methods. Curr Issues Multidisciplinary Microsc Res Educ 2, 72-80.

Navrátil, M., Válová, P., Fialová, R., Lauterer, P., Šafářová, D., \& Starý, M. (2009). The incidence of stolbur disease and associated yield losses in vegetable crops in South Moravia (Czech Republic). Crop Protection, 28(10), 898-904.

Oksal, H. D. (2020). Natural phytoplasma infections on fruit, vegetable and weed plants at the same agroecosystem and their molecular properties. Notulae Botanicae Horti Agrobotanici ClujNapoca, 48(2), 615-625.

Oksal, H. D., Apak, F. K., Oksal, E., Tursun, N., \& Sipahioglu, H. M. (2017). Detection and molecular characterization of two'Candidatus Phytoplasma trifolii'isolates infecting peppers at the same ecological niche. International Journal of Agriculture and Biology, 19(6), 1372-1378.

Pavlovic, S., Starović, M., Stojanovic, S.D., Kojic, S., Marinkovic, J., \& Josic, D. (2014). First report of stolbur phytoplasma affecting Cichorium intybus in Serbia. Plant disease, 98(6), 839-839.

Pérez-López, E., Dumonceaux, T.J., Olivier, C.Y., \& Luna-Rodríguez, M. (2014). Identification of 'Candidatus phytoplasma phoenicium'in periwinkle from Cuba. Revista Mexexicana de Fitopatología, 32, S47.

Pérez-López, E., Omar, A.F., Al-Jamhan, K.M., \& Dumonceaux, T.J. (2018). Molecular identification and characterization of the new 16SrIX-J and cpn60 UT IX-J phytoplasma subgroup associated with chicory bushy stunt disease in Saudi Arabia. International journal of systematic and evolutionary microbiology, 68(2), 518-522.

Pracros, P., Renaudin, J., Eveillard, S., Mouras, A., \& Hernould, M. (2006). Tomato flower abnormalities induced by stolbur phytoplasma infection are associated with changes of expression of floral development genes. Molecular Plant-Microbe Interactions, 19(1), 62-68.

Rashid, U., Bilal, S., Bhat, K.A., Shah, T.A., Wani, T.A., Bhat, F.A., \& Nazir, N. (2018). Phytoplasma effectors and their role in plant-insect interaction. International Journal of Current Microbiology and Applied Sciences, 7(2), 1136-1148.

Razin, S., Yogev, D., \& Naot, Y. (1998). Molecular biology and pathogenicity of mycoplasmas. Microbiology and molecular biology reviews, 62(4), 1094.

Sahtiyancı, Ş, (1966). Patates Stolbur virusü ve Türkiye'de İlk müşahadesi. Bitki Koruma Bülteni, 1(6), 24. 
Sakalieva, D. (2020). Molecular characterization of stolbur phytoplasmas in pepper and tomato from Bulgaria. BIO Web of Conferences 18, 00025 IV All-Russian Plant Protection Congress.

Seemüller, E., Marcone, C., Lauer, U., Ragozzino, A., \& Göschl, M. (1998). Current status of molecular classification of the phytoplasmas. Journal of Plant Pathology, 3-26.

Shimizu, K., \& Aoki, K. (2019). Development of parasitic organs of a stem holoparasitic plant in genus Cuscuta. Frontiers in plant science, 10, 1435.

Sugawara, K., Himeno, M., Keima, T., Kitazawa, Y., Maejima, K., Oshima, K., \& Namba, S. (2012). Rapid and reliable detection of phytoplasma by loop-mediated isothermal amplification targeting a housekeeping gene. Journal of general plant pathology, 78(6), 389-397.

Sugio, A., Kingdom, H. N., Nicholls, V. M., \& Hogenhout, S. A. (2010). The phytoplasma effector protein SAP11 improves vector fitness. Congr. Int. Org. Mycoplasmol., 18th, Cianciano Terme, $47,82$.

Sugio, A., MacLean, A. M., Grieve, V. M., \& Hogenhout, S. A. (2011). Phytoplasma protein effector SAP11 enhances insect vector reproduction by manipulating plant development and defense hormone biosynthesis. Proceedings of the National Academy of Sciences, 108(48), E1254E1263.

Suzuki, S., Oshima, K., Kakizawa, S., Arashida, R., Jung, H. Y., Yamaji, Y., Nishigawa, H., Ugaki M., \& Namba, S. (2006). Interaction between the membrane protein of a pathogen and insect microfilament complex determines insect-vector specificity. Proceedings of the National Academy of Sciences, 103(11), 4252-4257.

Tanrıkut, S. (1953). Domates yetiştiriciliği için tehlikeli bir hastalık. Bitki Koruma Bülteni, 5, 22-28.

Usta, M., Güller, A., \& Sipahioğlu, H. M. (2017). Detection and Characterization of two Phytoplasma lineages on Cucumber (Cucumis sativus L.) with Same Symptomatology based on Virtual RFLP and Nucleotide Sequence Analysis of 16S rDNA. Yüzüncü Yıl University Journal of Agricultural Sciences, 27, 299-308.

Usta, M., Güller, A., \& Sİpahİoğlu, H. M. (2018). Molecular analysis of'Candidatus Phytoplasma trifolii'and'Candidatus Phytoplasma solani'associated with phytoplasma diseases of tomato (PDT) in Turkey. International Journal of Agriculture and Biology, 20(9), 1991-1996.

Vandamme, P., Pot, B., Gillis, M., De Vos, P., Kersters, K., \& Swings, J. (1996). Polyphasic taxonomy, a consensus approach to bacterial systematics. Microbiological reviews, 60(2), 407.

Woese, C. R., Kandler, O., \& Wheelis, M. L. (1990). Towards a natural system of organisms: proposal for the domains Archaea, Bacteria, and Eucarya. Proceedings of the National Academy of Sciences, 87(12), 4576-4579.

Wu, J., \& Baldwin, I. T. (2010). New insights into plant responses to the attack from insect herbivores. Annual review of genetics, 44, 1-24. 